\title{
Review: Exchanges of volatile organic compounds between terrestrial ecosystems and the atmosphere
}

\author{
Akira TANI ${ }^{\dagger}$ and Tomoki MochIZUKI \\ Department of Environmental Sciences, Food and Nutritional Sciences, University of Shizuoka
$52-1$, Yada, Suruga-ku, Shizuoka 422-8526, Japan
}

\begin{abstract}
Many VOCs are reactive in the atmosphere, may produce secondary organic aerosol (SOA), and keep photochemical ozone concentrations high by VOC-involved reactions. Accumulated studies have shown the importance of terrestrial ecosystems which can be sinks and sources of VOCs. The research progress in the exchange of volatile organic compounds (VOCs) between terrestrial ecosystems and the atmosphere was reviewed in this paper. Representative VOCs emitted from terrestrial ecosystems are low-molecular-weight oxygenated VOCs including methanol, acetone, formic and acetic acids, and terpenoids, including isoprene and monoterpenes. Terpenoid emissions have been intensively investigated from the leaf to the canopy level using advanced analytical systems, including proton-transfer-reaction mass spectrometry. Environmental factors, including temperature, light intensity, carbon dioxide and ozone concentrations, and water stress have been reported to affect terpenoid emissions from plants. The combined effects of these environments influence terpenoid emission additively or interactively, and are important in terms of VOC emission estimates against ongoing climate change. Isoprene is most abundantly released into the atmosphere among VOCs; the potential reasons why some plants release such large amounts of carbon as isoprene were summarized in this study. Among oxygenated VOCs, some compounds, including isoprene oxygenates methacrolein and methyl vinyl ketone, are bidirectionally exchanged, and both atmospheric chemical reactions and reactions under oxidative stress in leaves have been regarded as involved in bidirectional VOC exchanges. Bottom-up process-based models and top-down inverse models have been developed to estimate global and local terpenoid emissions. To validate the accuracy and precision of the models, the collection of additional in-situ ground truth data, such as long-term flux measurement data, at various sites is required. Otherwise, these models may still leave large uncertainties compared with $\mathrm{CO}_{2}$ flux models that can be validated with a large number of ground truth flux data.
\end{abstract}

Key words: Bidirectional exchange, Canopy flux, Isoprene, Monoterpene, Process-based models, Volatile organic compounds

\section{Introduction}

In addition to greenhouse gases, many kinds of trace gas species are exchanged between terrestrial ecosystems and the atmosphere (Fig. 1). Some of them are emitted from biogenic sources, and others are anthropogenically produced. Several species are exchanged bilaterally.

Some of them are highly reactive in the atmosphere and have a short lifetime. These gases can produce other gas species via chemical reactions, and in some cases, the reactions are important in terms of atmospheric chemistry. More than 100 volatile organic compound (VOC) species are detectable in the atmosphere, even in forest air. Most of them are at sub-ppb $(\mathrm{v} / \mathrm{v})$ level. VOCs are considered to be involved in producing photochemical ozone and secondary organic aerosols (SOAs).

VOC and $\mathrm{NO}_{\mathrm{x}}$ emissions are believed to form photochemical

Received; April 21, 2020

Accepted; August 15, 2020

†Corresponding author: atani@u-shizuoka-ken.ac.jp

DOI: 10.2480/agrmet.D-20-00025

C) Author (s) 2021.

This is an open access article under the CC BY 4.0 license. ozone and degrade air quality in urban and sub-urban areas. $\mathrm{NO}$ in the atmosphere is produced from $\mathrm{NO}_{2}$ during daytime by sunlight (wavelength $<398 \mathrm{~nm}$ ). This NO is easily oxidized by $\mathrm{O}_{3}$ and peroxides to produce $\mathrm{NO}_{2}$. This is the reason why the NO concentration is very low compared with that of $\mathrm{NO}_{2}$. Peroxides are produced through a series of chemical reactions between VOCs and $\mathrm{OH}$ radicals. If the VOC concentration is high, NO reacts more frequently with the peroxides than with $\mathrm{O}_{3}$. This results in maintaining the ozone concentration at a higher level. In urban areas, the reduction of $\mathrm{NO}_{\mathrm{x}}$ and $\mathrm{VOC}$ emissions is essential to decrease the $\mathrm{O}_{3}$ concentration.

SOA is also produced from VOCs and affects human health and the climate. SOAs absorb and scatter shortwave radiation and affect cloud properties, as they serve as cloud condensation nuclei $(\mathrm{CCN})$ or ice nuclei by providing their surface for water vapor condensation to form liquid droplets and ice particles (Shrivastava et al., 2017). VOCs are degraded in the atmosphere by a number of reactions with $\mathrm{OH}$, ozone, $\mathrm{NO}_{3}$, and $\mathrm{HO}_{2}$ (Carlton et al., 2009). These oxidized products undergo gas-particle conversion processes such as nucleation, condensation, and heterogeneous and multiphase chemical reactions. The formation and growth of SOA depend on the original oxidized products. By mass balance calculation, Goldstein and Galbally (2007) estimated that 510-910 TgC $\mathrm{yr}^{-1}$ 


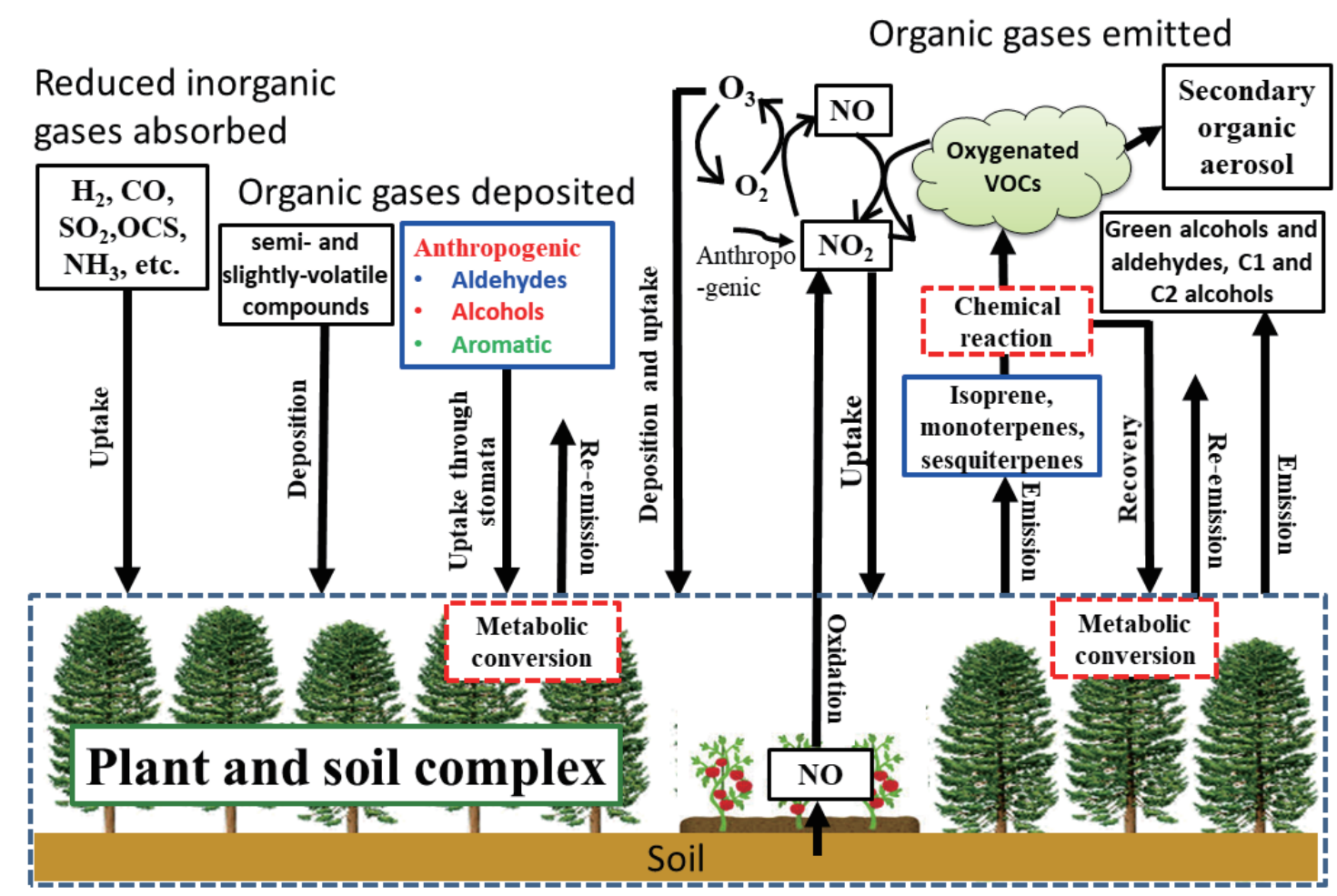

Fig. 1. Trace gas species exchanged between terrestrial ecosystem and atmosphere

of SOA was formed from globally emitted VOCs with an annual

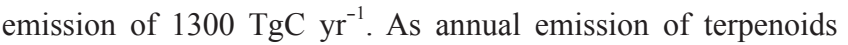
including isoprene and monoterpenes is estimated to be at least more than half of annual VOC emission (Arneth et al., 2008), terrestrial ecosystems may be strongly involved in the formation of photochemical ozone and SOA.

Hereinafter, we describe the characteristics of VOC, especially terpenoids, the effects of environmental factors on the exchange of these gases, and the perspective of their behavior affected by ongoing climate change.

\section{Trace gas species and atmospheric impacts}

\subsection{Isoprene}

\subsubsection{General}

Isoprene is an important secondary metabolite of plants and has a molecular formula of $\mathrm{C}_{5} \mathrm{H}_{8}$. It is volatile (b.p. $=34{ }^{\circ} \mathrm{C}$ ) and released into the atmosphere immediately after being produced. Isoprene is produced from dimethylallyl diphosphate (DMAPP) by isoprene synthase in chloroplasts. DMAPP is produced via the mevalonate pathway in cytosol and the methylerythritol 4-phosphate (MEP) pathway in chloroplasts.

As isoprene is very reactive with $\mathrm{OH}$ radicals, lifetime of isoprene in the reaction with $\mathrm{OH}$ radicals at a typical concentration $\left(2.0 \times 10^{6}\right.$ molecules $\left.\mathrm{cm}^{-3}\right)$ is $1.4 \mathrm{~h}$ (Atkinson and Arey, 2003). Isoprene is less reactive with ozone than with $\mathrm{OH}$ radicals, with a lifetime of 1.3 days at a typical ozone concentration $\left(7.0 \times 10^{11}\right.$ molecules $\left.\mathrm{cm}^{-3}\right)$. Because of its reactivities, isoprene is easily oxidized into methacrolein (MAC), methyl vinyl ketone (MVK), glycolaldehyde, and other compounds (Carlton et al., 2009). Further reactions of these compounds can lead to the formation of SOA and ozone. Even if the SOA yield from isoprene is $\sim 1 \%$, the large global source strength of isoprene may significantly contribute to the formation of SOA (Carlton et al., 2009). Details of SOA formation from isoprene have been described by Carlton et al. (2009).

Isoprene is emitted from many broadleaved trees and several coniferous trees (Table 1). Isoprene-emitting and non-emitting species can be found even within the same genus. There may be no consistent taxonomic relationships in the presence or absence of isoprene emission (Pacifico et al., 2009), but Harley et al. (1999) suggested that the occurrence of isoprene emissions may be involved in evolutionary history. In the genus Quercus, trees in section Cerris are non-emitters, whereas others in sections Rubrae, Quercus, and Protobalanus are isoprene emitters (Harley et al., 1999). In Quercus spp. occurring in East Asia, Tani and Kawawata (2008) revealed that Q. serrata, Q. crispula, $Q$. dentata, and Q. aliena in the Quercus section were all strong isoprene emitters, but some species in the Cerris section were non-emitters. The presence and absence of isoprene emission is unlikely to be categorized by functional type or climate range (Pacifico et al., 2009). The annual global emission of isoprene is estimated to be $459-601 \mathrm{TgC}$ by several models (Arneth et $a l ., 2008)$, which is higher than the annual emission estimates of anthropogenic VOCs $\left(98-158 \mathrm{TgC}^{-1}\right)$ (Boucher et al., 2013).

\subsubsection{Cost and benefit of isoprene production}

The ratio of carbon emitted in the form of isoprene to photosynthetically fixed carbon is $0.2 \%-5 \%$ depending on temperature and other environmental factors (e.g., Tani and Kawawata, 2008). Isoprene production requires 20 ATP and 14 NADPH per molecule (Sharkey and Yeh, 2001), and this significant cost is paid by isoprene-emitting species, but not by others. The physiological reason why some plants release such 
Table 1. Plant classification based on terpenoid emissions.

\begin{tabular}{|c|c|c|c|}
\hline category & storage or non-storage & plant type & representative species \\
\hline isoprene emitter & non-storage & $\begin{array}{c}\text { many deciduous trees and } \\
\text { grass }\end{array}$ & $\begin{array}{l}\text { Quercus serrata, Quercus crispula Blume, Quercus robur, } \\
\text { Pueraria montana, Liquidambar styraciflua, } \\
\text { Elaeocarpus serratus, Phyllostachys pubescens }\end{array}$ \\
\hline \multirow[t]{2}{*}{ monoterpene emitter } & storage & $\begin{array}{l}\text { most coniferous trees, } \\
\text { limited number of } \\
\text { deciduous trees, herbs }\end{array}$ & $\begin{array}{l}\text { Cryptomeria japonica, Chamaecyparis obtusa, } \\
\text { Pinus densiflora, Abies firma, Picea jezoensis, } \\
\text { Picea abies, Cinnamomum camphora, } \\
\text { Eucalyptus globulus, Salvia rosmarinus }\end{array}$ \\
\hline & non-storage & $\begin{array}{l}\text { limited number of } \\
\text { deciduous trees }\end{array}$ & $\begin{array}{l}\text { Fagus sylvatica, Quercus ilex, Quercus phillyraeoides, } \\
\text { Castanopsis cuspidata }\end{array}$ \\
\hline non-emitter & & $\begin{array}{l}\text { some deciduous and } \\
\text { coniferous trees }\end{array}$ & $\begin{array}{l}\text { Fagus crenata, Quercus acutissima, Quercus variabilis, } \\
\text { Castanea crenata, Cornus florida, Zelkova serrata, } \\
\text { Liriodendron tulipifera, Ilex rotunda, Nerium indicum }\end{array}$ \\
\hline
\end{tabular}

Some plant species emit both isoprene and monoterpenes, but based on dominant terpenoid species, they are categorized into either isoprene or monoterpene emitter.

large amounts of carbon as isoprene is not fully understood and many studies have been conducted. Thermal tolerance seems to be a plausible reason (Sharkey et al., 2007) as isoprene emission increases up to $\sim 40{ }^{\circ} \mathrm{C}$. Many studies have been undertaken to prove the thermotolerance hypothesis.

Singsaas et al. (1997) showed that when air containing several ppm isoprene was passed around leaf discs of an isoprene-emitting plant kudzu (Pueraria lobata), the temperature limit of thermal tolerance evaluated by chlorophyll fluorescence increased by as much as $4{ }^{\circ} \mathrm{C}$ in the least intense light and by as much as $10{ }^{\circ} \mathrm{C}$ in the more intense light. This suggests that exogenous and endogenous isoprene may help photosynthetic resistance against high temperatures. Sharkey et al. (2001) used fosmidomycin, which can inhibit isoprene emission without affecting photosynthesis for several hours. The decreased photosynthetic rate of $P$. lobata caused by a temperature treatment at $46{ }^{\circ} \mathrm{C}$ for $2 \mathrm{~min}$, recovered less in fosmidomycin-fed leaves than in leaves fed water or fosmidomycin-fed leaves in isoprene-containing air. The non-isoprene-emitting plant Phaseolus vulgaris exhibited increased photosynthetic recovery under a high temperature treatment when air containing $2-22 \mathrm{ppm}$ isoprene was supplied. These results indirectly suggest that isoprene can mitigate heat stress. Additionally, they show that other short-chain alkenes can also improve thermotolerance, while alkanes reduce thermotolerance.

A genetic approach seems to provide evidence that is more direct. Behnke et al. (2007) produced transgenic grey poplar (Populus $\times$ canescens) plants in which the gene expression of isoprene synthase (ISPS) was silenced by RNA interference (RNAi). The authors showed that lack of capacity for isoprene emission decreased the net photosynthetic rate and photosynthetic electron transport of poplars by heat stress. Velikova et al. (2014) suggested that a rearrangement of the chloroplast protein profile occurs in non-isoprene-emitting poplars, probably to minimize the negative stress effects caused by the absence of isoprene. As isoprene synthase was found to bind to the thylakoid membrane (Wildermuth and Fall, 1996), the results of Velikova et al. (2014) may support the idea that isoprene improves or stabilizes the thylakoid membrane structure under heat stress.
Other indirect approaches have been made from an ecosystem perspective. Taylor et al. (2018) estimated the proportional abundance of isoprene-emitting trees at 103 lowland tropical sites and revealed that the proportional abundance increased with the mean annual temperature of the sites. Taylor et al. (2019) compared the photosynthetic temperature responses of 26 co-occurring tropical trees and liana species to test whether isoprene-emitting species are more tolerant of high temperatures. They revealed that the maximum temperatures for net photosynthesis were $\sim 1.8{ }^{\circ} \mathrm{C}$ higher in isoprene-emitting species than in non-emitters.

The theory of isoprene defense against thermal stress has been expanded to other oxidative stresses (Sharkey and Yeh, 2001; Vickers et al., 2009a), as isoprene may act as an antioxidant in leaves owing to its high reactivity. Loreto and Velikova (2001) showed that fosmidomycin-fed leaves of isoprene-emitting plants were less tolerant to ozone. They estimated that isoprene quenched reactive oxygen species (ROS), including $\mathrm{H}_{2} \mathrm{O}_{2}$ and singlet delta oxygen (Zeinali et al., 2016) formed in leaves, and reduced the lipid peroxidation of cellular membranes caused by ozone. Vickers et al. (2009b) used transgenic tobacco plants capable of emitting isoprene and found that the isoprene-emitting plants were more resistant to ozone-induced oxidative damage than non-emitting controls. They also found that the content of reduced ascorbate in leaves, which functioned as an antioxidant, was higher in transgenic isoprene-emitting plants than in non-emitting plants, implying that the former contained antioxidant compounds in higher abundance. Isoprene directly reacts with ozone in leaves, producing hydroperoxides that are toxic to plants (Hewitt et al., 1990). However, the isoprene reaction with ozone is not fast (Atkinson and Arey, 2003), meaning that it may not work effectively even though the isoprene concentration inside the leaves is high $(\sim$ several tens $\mathrm{ppm}$ ). Isoprene may scavenge ROS generated in plants under other abiotic stresses, including intense light, water deficit, mechanical damage, salinity in soil, and other air pollutants (Vickers et al., 2009a). So far, it has become evident that isoprene acts as a ROS scavenging system in leaves. 


\subsection{Monoterpene and other terpenoids}

Monoterpene is the general name of a group of secondary metabolites produced by plants. The molecular formula of monoterpenes is $\mathrm{C}_{10} \mathrm{H}_{16}$. Monoterpenes are reactive in the atmosphere and emitted substantially. Monoterpenes are produced from geranyl diphosphate (GPP) by monoterpene synthase in plastids. Monoterpene alcohols $\mathrm{C}_{10} \mathrm{H}_{18} \mathrm{O}$ and ketones $\mathrm{C}_{10} \mathrm{H}_{16} \mathrm{O}$ are also included in the monoterpene family. They are volatile, but their boiling points are $>150{ }^{\circ} \mathrm{C}$, suggesting that they are produced in the liquid phase. Most monoterpene-emitting plants have specific storage organs and tissues, including oil glands and trichomes on leaf surfaces and resin ducts inside leaves, stems, or roots. Most coniferous trees have resin ducts and are classified as storage-type monoterpene emitters. Some broad-leaved trees, including those in the Eucalyptus genus and the Lauraceae family (Table 1), are categorized into the storage-type monoterpene emitters. Plants that have no storage organs are exceptions. They emit monoterpenes immediately after producing them. Some Quercus species, including Q. ilex (Staudt and Seufert, 1995) and Q. phillyraeoides (Okumura et al., 2008) are of the non-storage type.

Some of the monoterpene compounds are very reactive with $\mathrm{OH}$ radicals and ozone (Atkinson and Arey, 2003) in the atmosphere, causing the formation of SOA and ozone. The lifetimes of monoterpenes $\alpha$-pinene, $\beta$-pinene, and d-limonene with $\mathrm{OH}$ radicals at a typical concentration $\left(2.0 \times 10^{6}\right.$ molecules $\left.\mathrm{cm}^{-3}\right)$ are $2.6 \mathrm{~h}, 1.8 \mathrm{~h}$, and $49 \mathrm{~min}$, respectively, (Atkinson and Arey, 2003). Their lifetimes in the reaction with ozone at a typical ozone concentration $\left(7.0 \times 10^{11}\right.$ molecules $\left.\mathrm{cm}^{-3}\right)$ are $4.6 \mathrm{~h}, 1.1$ days, and $2.0 \mathrm{~h}$, respectively. The annual global emission of monoterpenes is estimated by several models to be $32-127 \mathrm{TgC}$ (Arneth et al., 2008).

The molecular formula of sesquiterpenes is $\mathrm{C}_{15} \mathrm{H}_{24}$. Because of their low volatility, their emission rate is generally low. However, they are produced and emitted after being fed to insects (Holopainen and Gershenzon, 2010). Sesquiterpene ketones and aldehydes are also often detected in plant emissions. Diterpenes are rarely detected in the atmosphere and is emitted by a very limited number of tree species. A large amount of kaur-16-ene was reported to be produced and emitted by Cryptomeria japonica (Matsunaga et al., 2012). Many of sesquiterpenes and diterpenes are reactive and low volatile, therefore easily converted to SOA in the atmosphere.

\subsection{Other biogenic gases}

Methanol and acetone are among the most abundant VOCs in the atmosphere (Jacob et al., 2002; 2005). Atmospheric methanol is oxidized by $\mathrm{OH}$ radicals to produce formaldehyde (Riemer et al., 1998). Methanol and formaldehyde are toxic organic air pollutants, and their emissions are regulated by the United States Environmental Protection Agency (EPA) and the Ministry of the Environment (Japan). Acetone is an important source of $\mathrm{HO}_{x}$ radicals (Singh et al., 1995) that contribute to the formation of ozone in the atmosphere.

Formic and acetic acids in the gas phase are the dominant organic acids in the atmosphere (Kawamura et al., 2000; Mochizuki et al., 2019). Gaseous formic and acetic acids are adsorbed on existing alkaline particles (Alexander et al., 2015). As formic and acetic acids are highly water soluble, they can alter the hygroscopic properties of atmospheric particles (Kanakidou et $a l ., 2005)$. It should be noted that organic acids contribute to the acidity of wet deposition (e.g., Kawamura et al., 1996).

Atmospheric concentrations of methanol, acetone, and formic and acetic acids range from a few ppt to several ppb (see Seco et al., 2007 and the references therein). The lifetimes of gaseous methanol and acetone reacting with $\mathrm{OH}$ radicals at a typical concentration $\left(2.0 \times 10^{6}\right.$ molecules $\left.\mathrm{cm}^{-3}\right)$ are 12 and 61 days, respectively (Atkinson and Arey, 2003). The lifetimes of gaseous formic and acetic acids reacting with $\mathrm{OH}$ radicals at a typical concentration $\left(2.0 \times 10^{6}\right.$ molecules $\left.\mathrm{cm}^{-3}\right)$ are 13 and 7.2 days, respectively (NIST Standard Reference Database Number 69), suggesting that their lifetimes are much longer than those of reactive hydrocarbons, such as isoprene and monoterpenes.

Methanol, acetone, and formic and acetic acids are directly emitted from plant leaves, leaf litter, and dead plant matter (Seco et al., 2007). Briefly, methanol is a product of pectin demethylation in the plant cell wall. Acetone is produced after the decarboxylation of acetoacetate, which is derived from acetyl-CoA in plant leaves. Formic acid is a product of the decarboxylation of glycolic acid during photorespiration. It is also produced through the oxidation of formaldehyde in plant leaves. Acetic acid is a product of the hydrolysis of acetyl-CoA. Several studies have found that emissions of methanol, acetone, and formic and acetic acids from plant leaves varied with temperature, light intensity, and stomatal conductance (Nemecek-Marshall et al., 1995; Kesselmeier et al., 1997; Janson and Serves, 2001). However, the available data on these compounds that are directly emitted by vegetation are limited, and their controlling factors are unclear. Formic and acetic acids are also produced secondarily from the photochemical oxidations of terpenoids, including isoprene and monoterpenes in the atmosphere (Paulot et al., 2011).

Methanol, acetone, and formic and acetic acids are emitted from a variety of anthropogenic and biogenic sources. The annual global emissions of methanol and acetone are estimated to be $187 \mathrm{Tg} \mathrm{yr}^{-1}$ (Stavrakou et al., 2011) and $95 \mathrm{Tg} \mathrm{yr}^{-1}$ (Jacob et $a l ., 2002)$, respectively. The annual emissions of methanol and acetone from terrestrial vegetation account for approximately 53\% and $35 \%$ of the annual global emissions, respectively. The annual global emissions of formic and acetic acids are estimated to be $57 \mathrm{Tg} \mathrm{yr}^{-1}$ and $85 \mathrm{Tg} \mathrm{yr}^{-1}$, respectively (Paulot et al., 2011). The emissions of formic and acetic acids from terrestrial vegetation account for $4.5 \%$ and $3.0 \%$ of the global emissions, respectively; conversely, the secondary production of formic and acetic acids via the photochemical oxidation of biogenic VOCs is estimated to account for $74 \%$ and $67 \%$ of the global emissions, respectively.

\subsection{Anthropogenic VOCs}

The fossil fuel burning and solvent industry release a wide variety of anthropogenic VOCs, including aliphatic hydrocarbons, aromatic hydrocarbons, ketones, aldehydes, and alcohols. Toluene is the most abundant compound in urban and rural atmosphere. Benzene is also ubiquitous and the second abundant compound. In general, the reactivity of 
these compounds is low compared with those of isoprene and monoterpenes. However, compounds with double or triple bonds, including acrolein, are more easily oxidized in the atmosphere.

Partitioning of anthropogenic VOCs from air phase to water phase is explained by Henry's law constant. Small amounts of benzene and toluene are partitioned into water phase but oxygenated VOCs including aldehydes, ketones and alcohols are largely partitioned into water phase. As plant leaves include water at a volume ratio of $>80 \%$, substantial amounts of these oxygenated compounds are partitioned in leaves. Some of them are metabolized in plant cells (Trapp and Karlson, 2001). Octanol/water partition coefficient is another index that determines the degree of partition of VOCs between plants and outside environments. Toluene is substantially stored in lipids of plant leaves (Keymeulen et al., 1997). Mobility of VOCs within plants from roots to leaves depends on the octanol/water partition coefficient and differs for different VOC species (Burken and Schnoor, 1998).

\section{Leaf, plant, and soil level exchanges}

\subsection{Isoprene emissions from leaves, branches, and individual trees}

Isoprene emissions from plants on the leaf and branch levels have been intensively measured in terms of plant physiology and atmospheric chemistry. By using a real-time isoprene analyzer, such as a chemiluminescence analyzer (Hills and Zimmerman, 1990) and a proton-transfer-reaction mass spectrometer (PTR-MS) (Lindinger et al., 1997), it is evident that isoprene emission is not affected by the degree of stomatal opening. This is different from the $\mathrm{CO}_{2}$ exchange on the leaf surface that is governed by stomatal conductance. This is because isoprene synthesis is not affected by the intercellular isoprene concentration. When the opening area of the stomata becomes narrow, the intercellular concentration immediately increases to equilibrate the isoprene production rate with its emission rate (Fall and Monson, 1992).

The temperature dependency of isoprene is governed by isoprene synthase. Analogous to most enzymes, its optimum temperature is $\sim 40{ }^{\circ} \mathrm{C}$. The isoprene emission rate increases with an increase in temperature up to $\sim 40{ }^{\circ} \mathrm{C}$ (Fig. 2). The light dependency of isoprene is closely related to the DMAPP production rate, which is affected by $\mathrm{CO}_{2}$ fixation via photosynthesis. The isoprene emission rate curve against light intensity is very similar to the curve of photosynthetic rate against light (Fig. 2). The light saturation point is between 200 and $1000 \mu \mathrm{mol} \mathrm{m} \mathrm{m}^{-2} \mathrm{~s}^{-1}$, depending on the sun exposure conditions of leaves (Harley et al., 1996, 1997; Hayward et al., 2004; Tani and Kawawata, 2008). The equations that express the isoprene emission rate depending on temperature and light intensity were developed by Guenther et al. (1993) and have been called the G93 algorithm. These equations have been widely used to estimate the isoprene emission rate not only on the leaf area and branch bases, but also on the plant and canopy levels.

The effect of elevated $\mathrm{CO}_{2}$ concentration on plant isoprene emissions has been investigated. Short-term fumigation can decrease the isoprene emission rate compared with ambient $\mathrm{CO}_{2}$ fumigation (e.g., Tingey et al., 1981). The isoprene precursor DMAPP is produced by the MEP pathway in chloroplasts, and phosphoenolpyruvate (PEP) is converted to pyruvate, which is
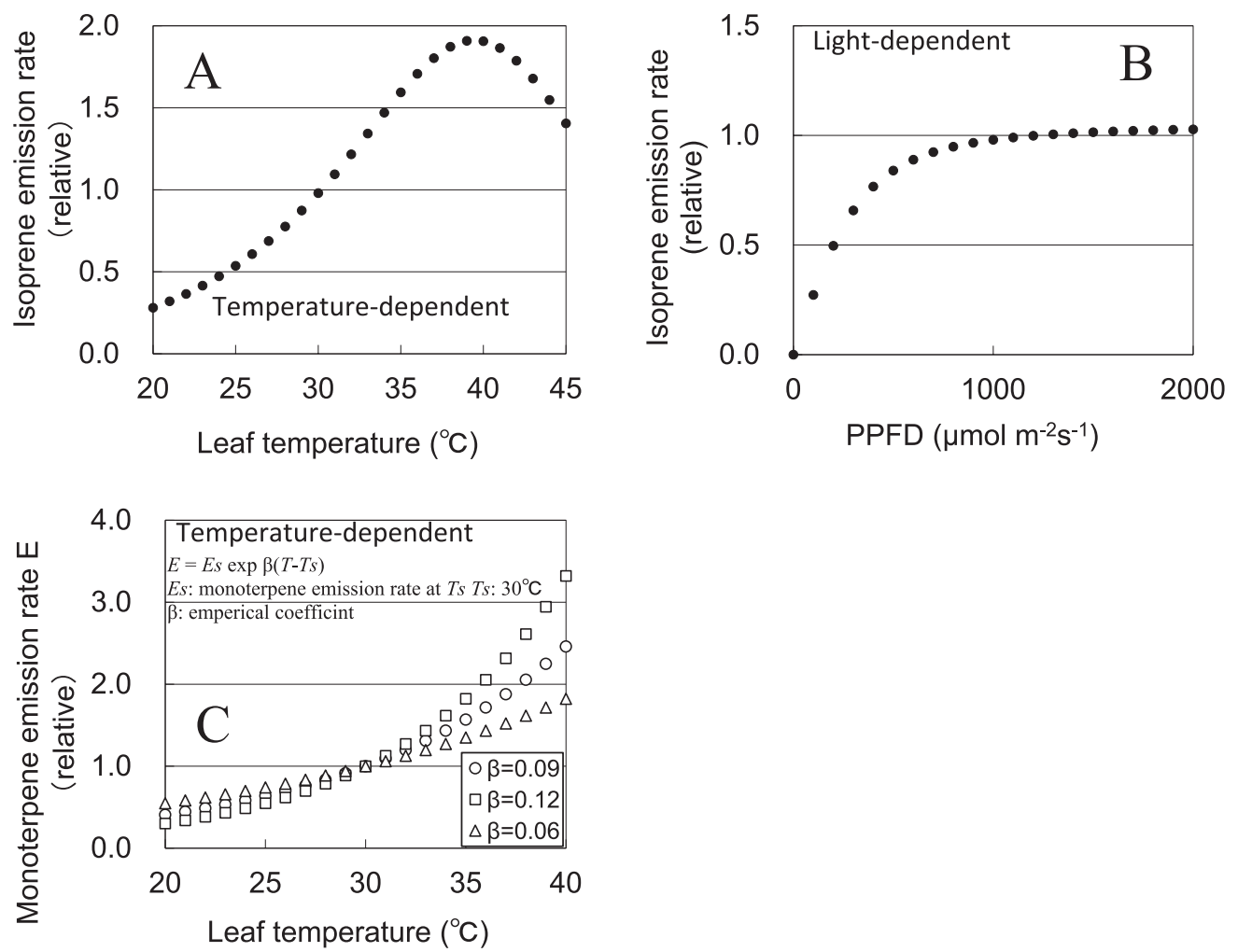

Fig. 2. Models describing temperature-dependent (A) and light-dependent (B) isoprene and temperature-dependent (C) monoterpene emissions. 
a substance of the MEP pathway. The elevated $\mathrm{CO}_{2}$ may result in a higher concentration of total leaf PEP, but cause a lower PEP concentration in the stroma when compared with ambient $\mathrm{CO}_{2}$ concentration. This stromal PEP contributes to isoprene production, and this change in this metabolic balance may cause an isoprene emission reduction. The details of this hypothesis are described by Sharkey and Monson (2014). Many reports suggest that long-term fumigation experiments with elevated $\mathrm{CO}_{2}$ may also result in the inhibition of isoprene emission (Rosenstiel et al., 2003; Scholefield et al., 2004; Monson et al., 2007), although a few reports have shown that it may increase the isoprene emission capacity (Sun et al., 2012; 2013). The inhibition of isoprene emission may be caused by a decreased activity of isoprene synthase (Scholefield et al., 2004; Possell and Hewitt, 2011) in addition to the lower PEP concentration in the stroma mentioned above.

Elevated $\mathrm{O}_{3}$ has been reported to increase isoprene production in several short-term fumigation experiments. Increased isoprene emission under $\sim 300 \mathrm{ppb} \mathrm{O}_{3}$ quenched $\mathrm{H}_{2} \mathrm{O}_{2}$ formed in the ozone-exposed leaves of Phragmites australis and reduced lipid peroxidation in the cellular membranes (Loreto and Velikova, 2001; Velikova et al., 2005). However, this protective effect was not obvious under long-term exposure with a possible concentration of $\mathrm{O}_{3}$ (ambient $+40 \mathrm{ppb}$ in many cases). The isoprene emission rate was reduced by long-term exposure, probably by the suppressed gene expression and protein level of isoprene synthase (Calfapietra et al., 2007, 2008) or the decreased production of DMAPP (Yuan et al., 2016, Tani et al., 2017). Under enriched $\mathrm{O}_{3}$ conditions, biomass was reported to be less decreased in aboveground parts, including leaves, than in the roots, in order to mitigate the decreased photosynthesis on the leaf area basis (Agathokleous et al., 2018). If this is the case, the isoprene emission rate of individual trees may be less decreased than the isoprene emission rate on the leaf area basis.

The effect of water stress on isoprene emission has been intensively investigated. The isoprene emission rate of Q. pubescens (Brüggemann and Schnitzler, 2002), Populus alba (Brilli et al., 2007), Q. rubra (Funk et al., 2005), P. deltoides (Funk et al., 2004; Pegoraro et al., 2004), and Liquidambar styraciflua (Fang et al., 1996) is reduced by water stress, but the degree of reduction is smaller than that of the photosynthetic reduction. Quercus serrata and Q. crispula, which are major tree species native to East Asia, continue to produce isoprene even when the gross photosynthetic rate becomes lower than the respiration rate during daytime (net photosynthetic rate $<0$ ) (Tani et al., 2011). Under normal conditions, DMAPP is supplied mainly from chloroplastic sources, but it may be supplied substantially from an alternative source in the cytosol. The cytosol source may be the primary precursor of isoprene under drought conditions (Karl et al., 2002; Schnitzler et al., 2004). Under severe drought conditions, the alternative source is so limited that the isoprene emission rate is low.

A change in land use may enhance the emission of isoprene from modified vegetation, including spreading bamboo forests (Okumura et al., 2018; Chang et al., 2019) and palm oil plantations (Wilkinson et al., 2006; Misztal et al., 2011; Dislich et al., 2017).

\subsection{Monoterpene emissions from leaf, branch, and individual tree}

Monoterpene emissions from non-storage types depend on temperature and light intensity, as does isoprene emission. It increases with temperatures of up to $\sim 40{ }^{\circ} \mathrm{C}$ and with photosynthetic photon flux density (PPFD) of up to $\sim 1000 \mu \mathrm{mol} \mathrm{m} \mathrm{m}^{-2} \mathrm{~s}^{-1}$ (Staudt and Seufert, 1995; Staudt and Bertin, 1998). Monoterpene emissions from storage type plants depend on temperature because monoterpene evaporates from storage organs following the temperature-dependent equation of saturated vapor pressure, which is similar to the Antoine equation. A more simplified equation was proposed by Guenther et al. (1993), as shown in Fig. 2. In this equation, coefficient $\beta$ determines the slope of the fitted curve. Coefficient $\beta$ can be calculated using datasets of the emission rate and temperature, and it is reported to have a wide range of values, that is, 0.02-0.13 within a strain of C. japonica (Miyama et al., 2019).

The effects of $\mathrm{CO}_{2}$, ozone, and water stress on monoterpene emissions from non-storage type trees are similar to those on isoprene emission (e.g., Loreto et al., 2001). However, the effects on monoterpene emissions from storage-type trees are not the same as those on isoprene emission and are not consistent among reports. No effects of elevated $\mathrm{CO}_{2}$ on the total monoterpene emission rate were observed for the evergreen coniferous tree Pinus sylvestris $\left(700 \mu \mathrm{mol} \mathrm{mol}{ }^{-1}\right.$ throughout a 5 year period) (Räisänen et al., 2008) and deciduous broadleaved tree Betula pendula clones (twice as much as the ambient $\mathrm{CO}_{2}$ concentration for two growing seasons) (Vuorinen et al., 2005). A negative effect of elevated $\mathrm{CO}_{2}$ on total monoterpene emissions was found for hybrid larch $\mathrm{F}_{1}$ (Larix gmelinii var. japonica $\times$ Larix kaempferi) (Mochizuki et al., 2017). Elevated $\mathrm{O}_{3}$ levels increase the total monoterpene emissions of deciduous Ginkgo biloba (Li et al., 2009) and C. japonica (Miyama et al., 2018), but they do not affect the total monoterpene emissions of deciduous B. pendula (Hartikainen et al., 2012) and hybrid larches (Mochizuki et al., 2017). However, ozone causes a change in the monoterpene composition in hybrid larch leaves; less reactive monoterpenes are abundantly emitted because $\mathrm{O}_{3}$ may react with monoterpenes in leaves (Mochizuki et al., 2017).

\subsection{Terpenoid emissions from soil}

Leaf litter, roots, forest floor plants, and the microbiological decomposition of organic matter are monoterpene sources (Hayward et al., 2001; Leff and Fierer, 2008; Ludley et al., 2009; Tsuruta et al., 2018). Their source strengths are diverse and differ among vegetation types. As for forest soil, the soil monoterpene emission rates in coniferous $P$. sylvestris (Ketola et al., 2011) and P. sitchensis (Hayward et al., 2001) forests were $0.86 \mathrm{nmol} \mathrm{m}^{-2} \mathrm{~s}^{-1}\left(8{ }^{\circ} \mathrm{C}\right.$ in soil temperature $)$ and $0.08 \mathrm{nmol} \mathrm{m}^{-2} \mathrm{~s}^{-1}$ $\left(18^{\circ} \mathrm{C}\right.$ in air chamber temperature), respectively. The soil monoterpene emission rate in a broadleaved $Q$. ilex forest was $0.004 \mathrm{nmol} \mathrm{m} \mathrm{m}^{-2} \mathrm{~s}^{-1}\left(8{ }^{\circ} \mathrm{C}\right.$ in soil temperature) (Asensio et $a l ., 2007)$. As for the forest floor including ground vegetation (e.g., herbaceous plants, fungi, and mosses), the monoterpene emission rate of the floor of $P$. sylvestris forests was reported to be $1.9 \mathrm{nmol} \mathrm{m}^{-2} \mathrm{~s}^{-1}\left(28^{\circ} \mathrm{C}\right.$ in air chamber temperature) (Aaltonen et al., 2013) and $0.013 \mathrm{nmol} \mathrm{m} \mathrm{m}^{-2} \mathrm{~s}^{-1}\left(7.5^{\circ} \mathrm{C}\right.$ in air chamber 
temperature) (Aaltonen et al., 2011).

Smolander et al. (2006) reported that the monoterpene concentration in the aerial space of soil in coniferous Picea abies and $P$. stlvestris forests were significantly higher than that in broadleaved Betula pendula forest. The monoterpene concentration in the aerial space of soil in a coniferous P. mariana (black spruce) forest was significantly higher than the atmospheric concentration above the forest (Morishita et al., 2019). Hayward et al. (2001) reported that monoterpene emission rates differed among soil depths, and needle litter was a strong source of monoterpenes. The monoterpene emission rate of the P. sylvestris forest floor was the highest in autumn (Aaltonen et al., 2011) and the observed seasonality was attributed to an increase in litter fall in autumn as the needle litter included monoterpenes. Coniferous forests floor/soil may be an important source of monoterpenes in the atmosphere.

Contrarily, the isoprene emission rate of a $P$. sylvestris forest floor was $0.0002 \mathrm{nmol} \mathrm{m} \mathrm{m}^{-2} \mathrm{~s}^{-1}$, which was much lower than the monoterpene emission rate at the same site (Aaltonen et al., 2011). The isoprene emission rate of arctic soil (Salix-Eriophorum community) measured at air temperature of $\sim 10{ }^{\circ} \mathrm{C}$ was $0.02 \mathrm{nmol} \mathrm{m}^{-2} \mathrm{~s}^{-1}$ (Svendsen et al., 2016).

\subsection{Leaf uptake of OVOCs}

Oxygenated VOCs, including low-molecular-weight alcohols, ketones, and aldehydes, have been reported to be absorbed by plants via stomata (Omasa et al., 2000; Tani and Hewitt, 2009; Tani et al., 2013). At the concentration range of ppb to several tens ppb, measurements based on PTR-MS provide more precise data than does GCMS (Tani et al., 2007). The uptake rate of ketones and aldehydes increases linearly with stomatal conductance $g_{S}$ (Tani et al., 2010; 2013), suggesting that the uptake is controlled by stomatal opening. However, its slope may become gentle when $g_{S}$ exceeds a certain level. This phenomenon has been reported for Spathiphyllum fumigated in propionaldehyde and methyl ethyl ketone (Tani and Hewitt, 2009). This is because the ratio of the intercellular concentration to the fumigated concentration of the gas species becomes higher owing to the limitation of metabolic conversion.

Isoprene oxygenates MAC and MVK are also absorbed by trees (Tani et al., 2010; Karl et al., 2010). MAC is metabolized in tissues to produce glutathione conjugates (Muramoto et al., 2015) and high-volatile compounds including isobutyl aldehyde, isobutyl alcohol, and methallyl alcohol when tomato plants are fumigated with MAC at the ppm level. Cappellin et al. (2019) recently reported that MVK absorbed by an isoprene-emitting species Quercus rubra was reduced in leaves to emit methyl ethyl ketone (MEK) or 3-buten-2-ol. Further reactions reduced MEK and 3-buten-2-ol to 2-butanol. A similar result has been reported by Tani et al. (2020), but they did not observe 3-buten-2-ol emission from non-isoprene-emitting species including three tree and one houseplant species. Cappellin et al. (2019) determined the conversion ratio of MVK to MEK to be $73 \%$, and that of MVK to all volatiles (including MEK, 3-buten-2-ol, and 2-butanol) to be $97.6 \%$, suggesting that the absorbed MEK was mostly converted to volatiles and scarcely remained in leaves. On the contrary, MVK conversion ratios of the non-isoprene-emitting species determined by Tani et al. (2020) were much lower than those reported by Cappellin et al. (2019); i.e. 26-39\% for MEK and 33-44\% for all volatiles. The difference in the conversion ratios from MVK to volatiles between two studies might be attributed to plant materials, i.e. isoprene-emitting or non-emitting species. Isoprene-emitting trees may have more active enzymes for converting MVK to volatiles than non-emitting plants, because cells of the isoprene-emitting plants are always exposed to high concentrations of isoprene oxygenates, including MVK, during daytime. This is because that MVK and MAC are formed in leaves by isoprene reaction under oxidative stress. (Jardine et al., 2010). As reactive carbonyl species including MVK and MACR are deleterious to plants at high concentrations (Mano, 2012; Farmer and Mueller, 2013), it may be safer for the isoprene-emitting plants to release the oxygenates into the atmosphere in the form of other volatiles because the pool size used for accumulating these oxygenates and their metabolites within plant tissues is limited.

It has been reported that some other VOCs are bilaterally exchanged between plants and the atmosphere (Niinemets et al., 2014). Four species of low molecular weight oxygenated VOCs (acetaldehyde, formaldehyde, and acetic and formic acids) are reported to be both emitted and taken up by plants (Kesselmeier, 2001). The compensation point of the compounds within leaves may vary, depending on their atmospheric concentration and production rate of these compounds within plants (Fares et al., 2015). Using an inverse model, a sink and source analysis of MACR and MVK was conducted by Wada et al. (2020), but their result suggests that larger amounts of data on spatial distribution of these compounds should be collected to provide a valid estimate.

\section{Ecosystem scale exchange}

\subsection{Flux measurement by micrometeorological techniques}

Flux measurement techniques employed for organic gases are theoretically the same as those employed for $\mathrm{CO}_{2}$ flux. The eddy covariance (EC) method may be applied for terpenoid fluxes. Fast-response analytical instruments including PTR-MS have been employed (Karl et al., 2001). In terpenoid flux measurements, PTR-MS can distinguish between VOCs of different molecular weights by using quadrupole or time of flight (TOF) mass filters. The TOF mass filter has the advantage of mass resolution as it allows the estimation of the molecular formula of the detected ions, though we cannot know whether the ions originate from molecular or fragment ions; in most cases they originate from both ion types, however we cannot be certain what percentage comes from molecular ions, which causes quantification and qualification uncertainties. Humidity affects the PTR-MS sensitivity and the fragment ion patterns of the proton-transfer-reaction products of monoterpenes (Tani et al., 2004), and these effects should not be ignored in certain cases. A theoretically determined concentration does not always provide an accurate absolute value of VOC concentrations (Kato et al., 2004) and requires correction using the known concentration of the target gas (Tani et al., 2003). To overcome these uncertainties, a recent study tried to improve the data handling method of PTR-MS based flux measurements (Millet et al., 2018). 
The relaxed accumulation method (REA) coupled with the thermal desorption method and gas chromatography mass spectrometry (GCMS) can provide a more reliable identification of each compound and more accurate concentrations (e.g., Mochizuki et al., 2014). The upward and downward airflows are separately accumulated into reservoirs and the determined concentrations of the two reservoirs are used for the flux calculation. The reservoir type is either canister or adsorbent tube.

The gradient method is also used for many trace gas species including terpenoids (Tani et al., 2002). This method was used in the early years of trace gas flux measurements. However, it is still used if measurement devices with high-time resolution for EC measurement are unavailable and if the gas species cannot be accumulated into REA reservoirs owing to its unstable characteristics. The concentration of the target gas at two different heights within the boundary layer above the tree canopy is measured and the difference between the two concentrations is divided by the height difference and multiplied by the diffusion coefficient of the target gas to determine its flux.

Other methods including the disjunct eddy sampling method (Rinne et al., 2000) have been developed. Although several methods to measure trace gas fluxes are available, the EC method may be advantageous from a timesaving point of view if fast-response analytical instruments provide reliable data.

\subsection{Terpenoid fluxes}

Isoprene and monoterpene fluxes have been reported for various forest types including boreal, cool temperate, temperate, Mediterranean, tropical, and savanna forests (Table 2). Broadleaved forests mainly emit isoprene and coniferous forests mainly emit monoterpenes. The canopy flux of isoprene in boreal and cool temperate, temperate and Mediterranean, and tropical

Table 2. Isoprene and monoterpene fluxes for various vegetation types.

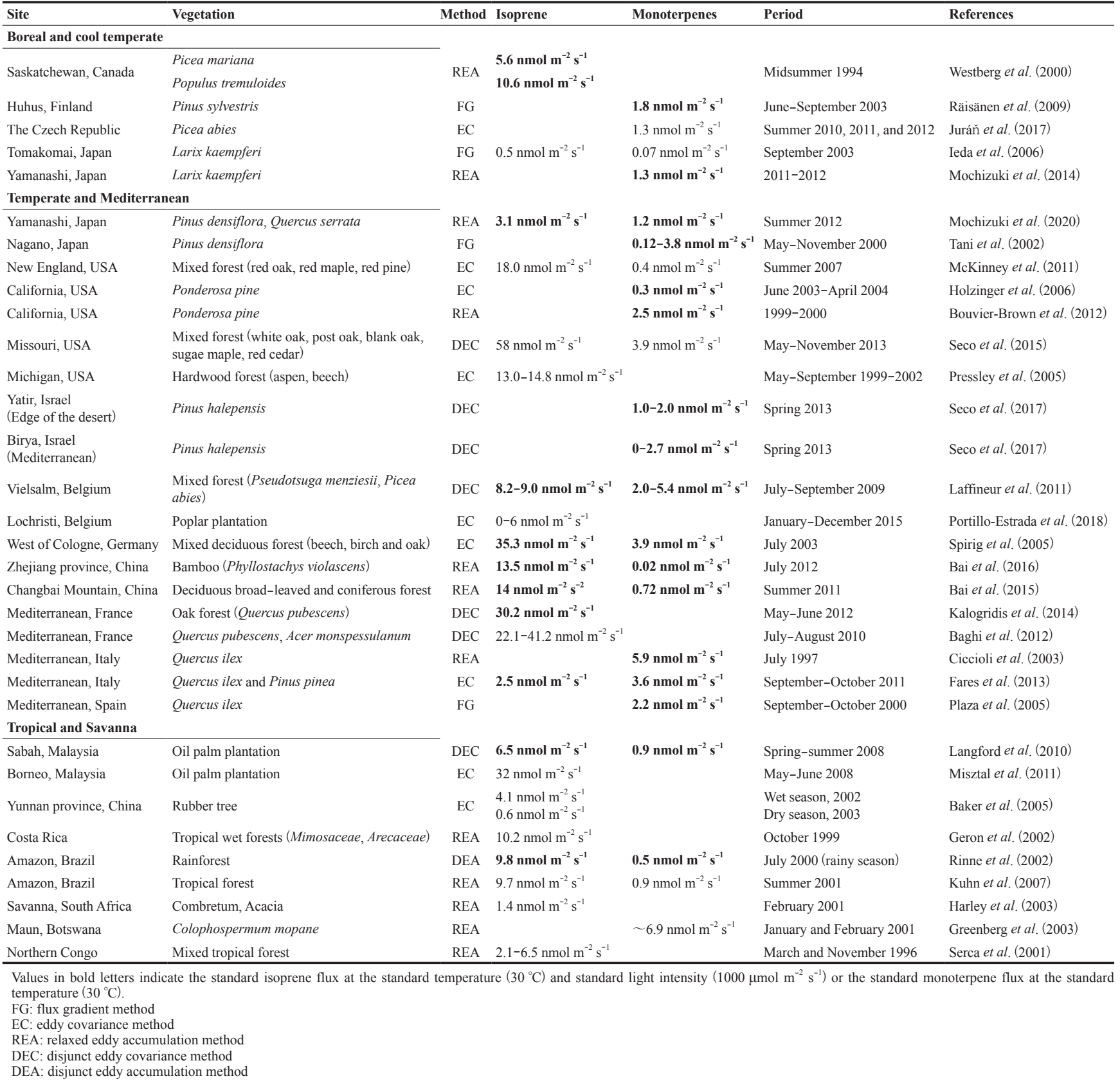


forests ranges from $0.5-10.6 \mathrm{nmol} \mathrm{m} \mathrm{m}^{-2} \mathrm{~s}^{-1}, 0-58 \mathrm{nmol} \mathrm{m}^{-2} \mathrm{~s}^{-1}$, and 1.4-32 nmol m $\mathrm{m}^{-2} \mathrm{~s}^{-1}$, respectively. Bamboo forests also emit isoprene (average flux $=13.5 \mathrm{nmol} \mathrm{m}^{-2} \mathrm{~s}^{-1}$ ). The canopy flux of monoterpene in boreal and cool temperate, temperate and Mediterranean, and tropical forests ranges from $0.07-1.8 \mathrm{nmol} \mathrm{m} \mathrm{m}^{-2} \mathrm{~s}^{-1}, 0.02-5.9 \mathrm{nmol} \mathrm{m}^{-2} \mathrm{~s}^{-1}$, and $0.5-6.9 \mathrm{nmol} \mathrm{m}^{-2} \mathrm{~s}^{-1}$, respectively. Relatively high monoterpene fluxes were observed in Mediterranean broadleaved forests and in savanna woodland areas (broadleaved trees) compared with coniferous forests. Overall, the canopy flux of isoprene is higher than that of monoterpenes.

Isoprene and monoterpenes include 5 and 10 carbon atoms, respectively, in each molecule. The emission of isoprene and monoterpenes is the loss of carbon fixed by photosynthesis. The annual carbon emissions as monoterpenes from a L. kaempferi forest (Mochizuki et al., 2014) and a P. ponderosa forest (Bouvier-Brown et al., 2012) was reported to account for $0.9 \%$ and $0.5 \%$, respectively, of the net ecosystem exchange of carbon (NEE). The annual carbon emission as isoprene from poplar plantations accounts for $0.3 \%$ of the NEE (Portillo-Estrada et $a l ., 2018$ ). Ignoring the loss of carbon emitted by isoprene and monoterpenes may result in an overestimation of the carbon stored in the forest ecosystem.

\subsection{Factors affecting ecosystem-level exchange of biogenic VOCs}

Generally, canopy-scale isoprene and monoterpene emissions start to increase in the morning and reach a peak around noon or in the afternoon, as they are affected by ambient air temperature and light intensity (Laffineur et al., 2011; Mochizuki et al., 2014; Seco et al., 2015; Mochizuki et al., 2020). However, higher monoterpene fluxes were observed in the morning than in the afternoon (Tani et al., 2002). This is because of the so-called storage effect.

A relatively high isoprene flux was observed in broadleaved mixed forests in the summer (Seco et al., 2015). The monoterpene fluxes of L. kaempferi and P. ponderosa forests are significantly higher in summer than in winter (Mochizuki et al., 2014; Holzinger et al., 2006). The seasonal variation in isoprene and monoterpene fluxes above the forest is not only linked to ambient air temperature variations, but is also involved in emission capacity changes caused by enzymatic activity. The monoterpene flux standardized to $30{ }^{\circ} \mathrm{C}$ is highest in early summer (June) in a $P$. densiflora forest (Tani et al., 2002).

High monoterpene flux in a $P$. ponderosa forest (Holzinger et al., 2006) and a L. kaempferi forest (Mochizuki et al., 2014) has been observed after rain events. Mochizuki et al. (2014) also reported that standardized monoterpene fluxes had a strong positive correlation with the volumetric soil water content, suggesting that rainfall enhances monoterpene emissions from larch forest ecosystems, including soils. In contrast, drought conditions had no impact on the isoprene flux of broadleaved mixed forests (Seco et al., 2015) and the monoterpene flux of Mediterranean pine forests (Seco et al., 2017), even though the net $\mathrm{CO}_{2}$ assimilation rate decreased.

When comparing the terpenoid emissions from the forest floor $\left(\mathrm{E}_{\text {floor }}\right)$ with canopy scale terpenoid fluxes $\left(\mathrm{E}_{\text {canopy }}\right)$, the ratio of $\mathrm{E}_{\text {floor }} / \mathrm{E}_{\text {canopy }}$ in a $P$. sylvestris forest in autumn (Aaltonen et al.,
2011) and a $P$. ponderosa forest (Greenberg et al., 2012) in the summer was $10 \%$ and $1 \%$, respectively. Janson (1993) observed a higher $\mathrm{E}_{\text {floor }} / \mathrm{E}_{\text {canopy }}$ ratio $(20-40 \%)$ under wet conditions. The soil and the forest floor may be important terpenoid emission sources from forest ecosystems, but their importance depends on the vegetation type, season, and environmental conditions. In particular, wet conditions may enhance monoterpene emissions from the soil and litter.

Long-term flux measurements may provide insight into the response of terrestrial ecosystems' terpenoid emissions to complex climate change. However, continuous or intermittent measurements of terpenoid fluxes for years have not been conducted. Compared with $\mathrm{CO}_{2}$ and $\mathrm{H}_{2} \mathrm{O}$ fluxes, it is difficult to operate the measurement devices automatically in order to measure the terpenoid concentrations. Only PTR-MS may be a candidate, but it requires careful operation and frequent maintenance. A limited number of researchers use PTR-MS for such exclusive monitoring for years.

\section{Combined effect analyses to address climate change effects}

Recent studies have focused on the combined effects of two or more environmental parameters on plant terpenoid emissions, in order to estimate the impact of ongoing climate change on terpenoid-related atmospheric chemistry and climate. For this study, leaf, branch, and individual tree measurements were conducted.

A combined experiment of long-term $\mathrm{CO}_{2}$ and $\mathrm{O}_{3}$ exposure was conducted by Calfapietra et al. (2008), the results of which suggest that the decline of isoprene emission under elevated $\mathrm{CO}_{2}$ and elevated $\mathrm{O}_{3}$ may be exacerbated by a combination of substrate $\left(\mathrm{CO}_{2}\right.$ effect $)$ and enzyme limitations $\left(\mathrm{O}_{3}\right.$ effect). The effects of $\mathrm{CO}_{2}$ and $\mathrm{O}_{3}$ on monoterpene emissions from $B$. pendula (Vuorinen et al., 2005) and P. sylvestris (Sallas et al., 2001) differed by season and monoterpene compounds.

The inhibition of isoprene production under elevated $\mathrm{CO}_{2}$ has been reported to be mitigated by high temperatures (Loreto and Sharkey, 1990; Sun et al., 2013; Potosnak et al., 2014). However, these experimental results are based on relatively short-term experiments and are not enough to provide an understanding of the mechanism responsible for the plants acclimated to elevated $\mathrm{CO}_{2}$ or high temperature.

Mochizuki et al. (2018) measured the monoterpene emission rate of $C$. japonica clone saplings grown at elevated $\mathrm{CO}_{2}$ conditions in an open-top chamber. The normalized monoterpene emission rates were positively and linearly correlated with soil water content $(\mathrm{SWC})$ under both the control and elevated $\mathrm{CO}_{2}$ conditions, but the slope of the regression line between them was significantly higher under the elevated $\mathrm{CO}_{2}$ conditions, indicating that the monoterpene emissions from plants grown under elevated $\mathrm{CO}_{2}$ conditions are more sensitive to SWC.

The combined effects of $\mathrm{O}_{3}$ and nitrogen on plant terpenoid emissions have been investigated (Llusià et al., 2014; Carriero et al., 2016; Yuan et al., 2017). The results of these studies suggest that the effects of $\mathrm{O}_{3}$ and $\mathrm{N}$ on terpenoid emission from plants are additive and not interactive. More complicated effects of elevated $\mathrm{CO}_{2}$ and $\mathrm{O}_{3}$ and high temperature on herbivore-induced terpenoid emissions 
were addressed by Kivimäenpää et al. (2016) and Ghimire et al. (2017). They showed a dramatic increase in total sesquiterpene emissions from the fed shoots of $B$. pendula and $P$. sylvestris in combination with high temperature and elevated ozone.

\section{Model estimates and satellite measurements to address climate change effects}

Based on the findings of leaf, branch, and individual tree measurements, several process-based models have been developed to estimate global and local terpenoid emissions (Arneth et al., 2008). Most of the models employ the G93 algorithm (i.e., the MEGAN model by Guenther et al. (2006)), while others include a model based on energetic requirements for isoprene synthesis (Niinemets et al., 1999). Using the process-based models, coupled with leaf area index (LAI), land cover data, vegetation lists classified as terpenoid emission type, and climate data, terpenoid emissions on global (Pacifico et al., 2012; Sindelarova et al., 2014) and regional (Ren et al., 2014; 2017; Bauwens et al., 2018) scales have been estimated for the past, present, and future. The resolution of climate data (Ashworth et al., 2010) and plant classification (Arneth et al., 2013) has been suggested to affect the accuracy of the terpenoid emission estimates. The tower-flux measurement data from a very limited number of vegetation types were compared with the model estimates for the sites to investigate the validity of the models (Sindelarova et al., 2014; Bauwens et al., 2018). Because of the limited number of flux data at individual sites, the comparisons showed fair agreement. Future estimates of global isoprene emissions based on climate change scenarios indicate that the isoprene emission may increase because of global warming, but this could be inhibited by a $\mathrm{CO}_{2}$ increase. The degree of change in global isoprene emission estimates depends on the model characteristics, vegetation data, and future scenarios (Pacifico et al., 2012; Bauwens et al., 2018). Ozone and SOA formations have been estimated according to the global warming scenario with a process-based isoprene emission model coupled with an atmospheric chemistry model. Pacifico et al. (2012) suggest that the ozone and SOA burden into the atmosphere may increase by $15 \%$ and two-fold, respectively, in the future (2100-2109) compared with the present levels.

Top-down isoprene emission models have also been developed using space-based formaldehyde ( $\mathrm{HCHO}$ ) vertical columns, as observed by the ozone monitoring instrument (OMI) (Levelt et al., 2006) and scanning imaging absorption spectrometer for atmospheric chartography (SCIAMACHY) (Bovensmann et al., 1999). As HCHO is an oxidation product of most VOCs emitted by biomass burning, vegetation, and anthropogenic activities, satellite observations of $\mathrm{HCHO}$ may provide information on the underlying VOC sources. Barkley et al. (2013) showed that the annual isoprene emission over tropical South America estimated by the SCIAMACHY column was two times higher than that estimated by the OMI column, the reason of which could not be explained by sampling time of sensors and cloud products by the air-mass factor (AMF) calculation. Bauwens et al. (2016) compared the inverse analysis using the $\mathrm{HCHO}$ vertical column with the MEGAN bottom-up model and discussed the reason for the difference in isoprene emission estimates. Recently, Fu et al. (2019) showed the possibility of the direct measurement of isoprene columns from space using the satellite-borne cross-track infrared sounder (CrIS). If the model based on the isoprene column is verified by ground truth data at multiple sites, the approach has the potential to become a more reliable method to estimate isoprene emission sources and their strength from space.

To validate the global and local terpenoid emissions estimated from bottom-up process-based models and top-down satellite estimates, a comparison between the two different methods may not lead to realistic results. To validate the accuracy and precision of the models, much more in-situ ground truth data, such as long-term flux and concentration measurement data at various sites, are required. As accumulated in-situ flux data may indicate a good relationship between the measured flux and environmental factors (e.g., Mochizuki et al., 2014), the data can be used to validate the developed models. Otherwise, these models may still leave large uncertainties compared with global carbon exchange models that can be validated with a large number of ground truth flux data.

\section{Acknowledgements}

This work was supported by MEXT KAKENHI Grant Number No. 19H04257, 19H05666 and 18K18181.

\section{References}

Aaltonen H, Aalto J, Kolari P et al., 2013: Continuous VOC flux measurements on boreal forest floor. Plant and Soil 369, 241-256.

Aaltonen H, Pumpanen J, Pihlatie M et al., 2011: Boreal pine forest floor biogenic volatile organic compound emissions peak in early summer and autumn. Agricultural and Forest Meteorology 151, 682-691.

Agathokleous E, Belz RG, Kitao M et al., 2018: Does the root to shoot ratio show a hermetic response to stress? An ecological and environmental perspective. Journal of Forest Research 30, 1569-1580.

Alexander JM, Grassian VH, Young MA et al., 2015: Optical properties of selected components of mineral dust aerosol processed with organic acids and humic material. Journal of Geophysical Research: Atmosphere 120, 2437-2452.

Arneth A, Monson RK, Schurgers G et al., 2008: Why are estimates of global terrestrial isoprene emissions so similar (and why is this not so for monoterpenes)? Atmospheric Chemistry and Physics 8, 4605-4620.

Arneth A, Schurgers G, Lathiere J et al., 2013: Global terrestrial isoprene emission models: sensitivity to variability in climate and vegetation. Atmospheric Chemistry and Physics 11, 8037-8052.

Asensio D, Peñuelas J, Llusià J et al., 2007: Interannual and interseasonal soil $\mathrm{CO}_{2}$ efflux and $\mathrm{VOC}$ exchange rates in a Mediterranean holm oak forest in response to experimental drought. Soil Biology \& Biochemistry 39, 2471-2484.

Ashworth K, Wild O, Hewitt CN, 2010: Sensitivity of isoprene emissions estimated using MEGAN to the time resolution of input climate data. Atmospheric Chemistry and Physics 10, 1193-1201.

Atkinson R, Arey J, 2003: Gas-phase tropospheric chemistry of biogenic volatile organic compounds: a review. Atmospheric Environment 37, Supplement No. 2, S197-S219.

Baghi R, Durand P, Jambert C et al., 2012: A new disjunct eddy-covariance system for BVOC flux measurements-validation 
on $\mathrm{CO}_{2}$ and $\mathrm{H}_{2} \mathrm{O}$ fluxes. Atmospheric Measurement Techniques 5, 3119-3132.

Bai J, Guenther A, Turnipseed A et al., 2015: Seasonal and interannual variations in whole-ecosystem isoprene and monoterpene emissions from a temperate mixed forest in Northern China. Atmospheric Pollution Research 6, 696-707.

Bai J, Guenther A, Turnipseed A et al., 2016: Seasonal variations in whole-ecosystem BVOC emissions from a subtropical bamboo plantation in China. Atmospheric Environment 124, 12-21.

Baker B, Bai JH, Johnson C et al., 2005: Wet and dry season ecosystem level fluxes of isoprene and monoterpenes from a southeast Asian secondary forest and rubber tree plantation. Atmospheric Environment 39, 381-390.

Barkley MP, De Smedt I, Van Roozendael M et al., 2013: Top-down isoprene emissions over tropical South America inferred from SCIAMACHY and OMI formaldehyde columns. Journal of Geophysical Research: Atmosphere 118, 6849-6868.

Bauwens M, Stavrakou T, Muller JF et al., 2016: Nine years of global hydrocarbon emissions based on source inversion of OMI formaldehyde observations. Atmospheric Chemistry and Physics 16, 10133-10158.

Bauwens M, Stavrakou T, Müller J-F et al., 2018: Recent past (1979-2014) and future (2070-2099) isoprene fluxes over Europe simulated with the MEGAN-MOHYCAN model. Biogeosciences 15, 3673-3690.

Behnke K, Ehlting B, Teuber M et al., 2007: Transgenic, non isoprene emitting poplars don't like it hot. Plant Journal 51, 485-499.

Boucher O, Randall D, Artaxo P et al., 2013: Clouds and Aerosols. In "Climate Change 2013: The Physical Science Basis. Contribution of Working Group I to the Fifth Assessment Report of the Intergovernmental Panel on Climate Change" ("edited by" Stocker TF, Qin D, Plattner G-K et al.). Cambridge University Press, Cambridge, United Kingdom and New York, NY, USA, "pp." 571-657.

Bouvier-Brown N, Schade G, Mission L et al., 2012: Contributions of biogenic volatile organic compounds to net ecosystem carbon flux in a ponderosa pine plantation. Atmospheric Environment 60, 527-533.

Bovensmann H, Burrows JP, Buchwitz M et al., 1999: SCIAMACHY: Mission objectives and measurement modes. Journal of the Atmospheric Sciences 56, 127-150.

Brilli F, Barta C, Fortunati A et al., 2007: Response of isoprene emission and carbon metabolism to drought in white poplar (Populus alba) saplings. New Phytologist 175, 244-254.

Brüggemann N, Schnitzler JP, 2002: Comparison of isoprene emission, intercellular isoprene concentration and photosynthetic performance in water-limited oak (Quercus pubescens Willd. and Quercus robur L.) saplings. Plant Biology 4, 456-463.

Burken JJ, Schnoor A, 1998: Predictive relationships for uptake of organic contaminants by hybrid poplar trees. Environmental Science \& Technology 32, 3379-3385.

Calfapietra C, Mugnozza GS, Karnosky DF et al., 2008: Isoprene emission rates under elevated $\mathrm{CO}_{2}$ and $\mathrm{O}_{3}$ in two field-grown aspen clones differing in their sensitivity to $\mathrm{O}_{3}$. New Phytologist 179(1), 55-61.

Calfapietra C, Wiberley AE, Falbel TG et al., 2007: Isoprene synthase expression and protein levels are reduced under elevated $\mathrm{O}_{3}$ but not under elevated $\mathrm{CO}_{2}$ (FACE) in field-grown aspen trees. Plant, Cell \& Environment 30, 654-661.
Cappellin L, Loreto F, Biasioli F et al., 2019: A mechanism for biogenic production and emission of MEK from MVK decoupled from isoprene biosynthesis. Atmospheric Chemistry and Physics 19, 3125-3135.

Carlton AG, Wiedinmyer C, Kroll JH, 2009: A review of Secondary Organic Aerosol (SOA) formation from isoprene. Atmospheric Chemistry and Physics 9, 4987-5005.

Carriero G, Brunetti C, Fares S et al., 2016: BVOC responses to realistic nitrogen fertilization and ozone exposure in silver birch. Environmental Pollution 213, 988-995.

Chang T, Kume T, Okumura M et al., 2019: Characteristics of isoprene emission from moso bamboo leaves in a forest in central Taiwan. Atmospheric Environment 211, 288-295.

Ciccioli P, Brancaleoni E, Frattoni M et al., 2003: Relaxed eddy accumulation, a new technique for measuring emission and deposition fluxes of volatile organic compounds by capillary gas chromatography and mass spectrometry. Journal of Chromatography A 985, 283-296.

Dislich C, Keyel AC, Salecker J et al., 2017: A review of the ecosystem functions in oil palm plantations, using forests as a reference system. Biological Reviews of the Cambridge Philosophical Society 49, 1539-1569.

Fall R, Monson RK, 1992: Isoprene emission rate and intercellular isoprene concentration as influenced by stomatal distribution and conductance. Plant Physiology 100, 987-992.

Fang C, Monson RK, Cowling EB, 1996: Isoprene emission, photosynthesis, and growth in sweetgum (Liquidambar styraciflua) seedlings exposed to short- and long-term drying cycles. Tree Physiology 16(4), 441-446.

Fares S, Paoletti E, Loreto F et al., 2015: Bidirectional flux of methyl vinyl ketone and methacrolein in trees with different isoprenoids emission under realistic ambient concentrations. Environmental Science \& Technology 49, 7735-7742.

Fares S, Schnitzhofer R, Jiang X et al., 2013: Observations of diurnal to weekly variations of monoterpene-dominated fluxes of volatile organic compounds from Mediterranean forests: Implications for regional modeling. Environmental Science \& Technology 47, 11073-11082.

Farmer EE, Mueller MJ, 2013: ROS-mediated lipid peroxidation and RES activated signaling. Annual Review of Plant Biology 64, 429-450.

Fu D, Millet DB, Wells KC et al., 2019: Direct retrieval of isoprene from satellite-based infrared measurements. Nature Communications 10(1), 3811.

Funk JL, Jones CG, Gray Dennis W et al., 2005: Variation in isoprene emission from Quercus rubra: sources, causes, and consequences for estimating fluxes. Journal of Geophysical Research 110, D04301.

Funk JL, Mak JE, Lerdau MT, 2004: Stress-induced changes in carbon sources for isoprene production in Populus deltoides. Plant, Cell \& Environment 27(6), 747-755.

Geron C, Guenther A, Greenberg J et al., 2002: Biogenic volatile organic compound emissions from a lowland tropical wet forest in Costa Rica. Atmospheric Environment 36, 3793-3802.

Ghimire RP, Kivimäenpää M, Kasurinen A et al., 2017: Herbivore-induced BVOC emissions of Scots pine under warming, elevated ozone and increased nitrogen availability in an open-field exposure. Agricultural and Forest Meteorology 242, 21-32.

Goldstein A, Galbally I, 2007: Known and unexplored organic constituents in the Earth's atmosphere. Environmental Science \& Technology 40, 1514-1521. 
Greenberg JP, Asensio D, Turnipseed A et al., 2012: Contribution of leaf and needle litter to whole ecosystem BVOC fluxes. Atmospheric Environment 59, 302-311.

Greenberg JP, Guenther A, Harley P et al., 2003: Eddy flux and leaf-level measurements of biogenic VOC emissions from mopane woodland of Botswana. Journal of Geophysical Research 108(D13), 8466.

Guenther A, Karl T, Harley P et al., 2006: Estimates of global terrestrial isoprene emissions using MEGAN (Model of Emissions of Gases and Aerosols from Nature). Atmospheric Chemistry and Physics 6, 3181-3210.

Guenther AB, Zimmerman PR, Harley PC et al., 1993: Isoprene and monoterpene emission rate variability: model evaluations and sensitivity analyses. Journal of Geophysical Research 98, 12609-12617.

Harley P, Guenther A, Zimmerman P, 1996: Effects of light, temperature and canopy position on net photosynthesis and isoprene emission from sweetgum (Liquidambar styraciflua) leaves. Tree Physiology 16, 25-32.

Harley P, Guenther A, Zimmerman P, 1997: Environmental controls over isoprene emission in deciduous oak canopies. Tree Physiology 17, 705-714.

Harley P, Monson RK, Lerdau MT, 1999: Ecological and evolutionary aspects of isoprene emission from plants. Oecologia 118, 109-123.

Harley P, Otter L, Guenther A et al., 2003: Micrometeorological and leaf-level measurements of isoprene emissions from a southern African savanna. Journal of Geophysical Research 108(D13), 8468.

Hartikainen K, Riikonen J, Nerg AM et al., 2012: Impact of elevated temperature and ozone on the emission of volatile organic compounds and gas exchange of silver birch (Betula pendula Roth). Environmental and Experimental Botany 84, $33-43$.

Hayward S, Muncey RJ, James AE et al., 2001: Monoterpene emissions from soil in a Sitka spruce forest. Atmospheric Environment 35, 4081-4087.

Hayward S, Tani A, Owen S et al., 2004: Online analysis of volatile organic compound emissions from Sitka spruce (Picea sitchensis). Tree Physiology 24, 721-728.

Hewitt CN, Kok GL, Fall R, 1990: Hydroperoxides in plants exposed to ozone mediate air pollution damage to alkene emitters. Nature 344, 56-58.

Hills AJ, Zimmerman PR, 1990: Isoprene measurement by ozone-induced chemiluminescence. Analytical Chemistry 62, 1055-1060.

Holopainen JK, Gershenzon J, 2010: Multiple stress factors and the emission of plant VOCs. Trends in Plant Science 15, 176-184.

Holzinger R, Lee A, McKay M et al., 2006: Seasonal variability of monoterpene emission factors for a Ponderosa pine plantation in California. Atmospheric Chemistry and Physics 6, 1267-1274.

Ieda T, Kitamori Y, Mochida M et al., 2006: Diurnal variations and vertical gradients of biogenic volatile and semi-volatile organic compounds at the Tomakomai larch forest station in Japan. Tellus 59B, 177-186.

Jacob DJ, Field BD, Jin EM et al., 2002: Atmospheric budget of acetone. Journal of Geophysical Research 107, D104100.

Jacob DJ, Field BD, Li Q et al., 2005: Global budget of methanol: Constraints from atmospheric observations. Journal of Geophysical Research 110, D08303.

Janson RW, 1993: Monoterpene emissions from Scots pine and
Norwegian spruce. Journal of Geophysical Research 98, 2839-2850.

Janson R, de Serves C, 2001: Acetone and monoterpene emissions from the boreal forest in northern Europe. Atmospheric Environment 35, 4629-4637.

Jardine K, Abrell L, Kurc SA et al., 2010: Volatile organic compound emissions from Larrea tridentata (creosotebush). Atmospheric Chemistry and Physics 10, 12191-12206.

Jurán̆ S, Pallozzi E, Guidolotti G et al., 2017: Fluxes of biogenic volatile organic compounds above temperate Norway spruce forest. Agricultural and Forest Meteorology 232, 500-513.

Kalogridis C, Gros V, Sarda-Esteve R et al., 2014: Concentrations and fluxes of isoprene and oxygenated VOCs at a French Mediterranean oak forest. Atmospheric Chemistry and Physics 14, 10085-10102.

Kanakidou M, Seinfeld JH, Pandis SN et al., 2005: Organic aerosol and global climate modeling: a review. Atmospheric Chemistry and Physics 5, 1053-1123.

Karl T, Fall R, Rosenstiel TN et al., 2002: On-line analysis of the $\mathrm{CO}_{2}$ labeling of leaf isoprene suggests multiple subcellular origins of isoprene precursors. Planta 215, 894-905.

Karl T, Guenther A, Jordan A et al., 2001: Eddy covariance measurement of biogenic oxygenated VOC emissions from hay harvesting. Atmospheric Environment 35, 491-495.

Karl T, Harley P, Emmons L et al., 2010: Efficient atmospheric cleansing of oxidized organic trace gases by vegetation. Science 330, 816-819.

Kato S, Miyakawa Y, Kaneko T et al., 2004: Urban air measurements using PTR-MS in Tokyo area and comparison with GC-FID measurement. International Journal of Mass Spectrometry 253, 103-110.

Kawamura K, Steinberg S, Kaplan IR, 1996: Concentrations of monocarboxylic and dicarboxylic acids and aldehydes in southern California wet precipitations: comparison of urban and nonurban samples and compositional changes during scavenging. Atmospheric Environment 30, 1035-1052.

Kawamura K, Steinberg S, Kaplan IR, 2000: Homologus series of $\mathrm{C}_{1}-\mathrm{C}_{10}$ monocarboxylic acids and $\mathrm{C}_{1}-\mathrm{C}_{6}$ carbonyls in Los Angeles air and motor vehicle exhausts. Atmospheric Environment 34, 4175-4191.

Kesselmeier J, 2001: Exchange of short-chain oxygenated volatile organic compounds (VOCs) between plants and the atmosphere: A compilation of field and laboratory studies. Journal of Atmospheric Chemistry 39, 219-233.

Kesselmeier J, Bode K, Hofmann U et al., 1997: Emission of short chained organic acids, aldehydes and monoterpenes from Quercus ilex L. and Pinus pinea L. in relation to physiological activities, carbon budget and emission algorithms. Atmospheric Environment 31, 119-133.

Ketola RA, Kiuru JT, Kotiaho T et al., 2011: Feasibility of membrane inlet mass spectrometry for on-site screening of volatile monoterpenes and monoterpene alcohols in forest soil atmosphere. Boreal Environmental Research 16, 36-46.

Keymeulen R, Parewijck B, GornaBinkul A et al., 1997: Determination of partition coefficients of monocyclic aromatic hydrocarbons between leaf essential oil and air by headspace gas chromatography. Journal of Chromatography A $\mathbf{7 6 5}$, 247-253.

Kivimäenpää M, Ghimire RP, Sutinen S et al., 2016: Increases in volatile organic compound emissions of Scots pine in response to elevated ozone and warming are modified by herbivory and soil nitrogen availability. European Journal of 
Forest Research 135, 343-360.

Kuhn U, Andreae MO, Ammann C et al., 2007: Isoprene and monoterpene fluxes from Central Amazonian rainforest inferred from tower-based and airborne measurements, and implications on the atmospheric chemistry and the local carbon budget. Atmospheric Chemistry and Physics 7, 2855-2879.

Laffineur Q, Aubinet M, Schoon N et al., 2011: Isoprene and monoterpene emissions from a mixed temperate forest. Atmospheric Environment 45, 3157-3168.

Langford B, Misztal PK, Nemitz E et al., 2010: Fluxes and concentrations of volatile organic compounds from a South-East Asian tropical rainforest. Atmospheric Chemistry and Physics 10, 8391-8412.

Leff JW, Fierer N, 2008: Volatile organic compound (VOC) emissions from soil and litter samples. Soil Biology \& Biochemistry 40, 1629-1636.

Levelt PF, van den Oord GHJ, Dobber MR et al., 2006: The Ozone monitoring instrument. IEEE Transactions on Geoscience and Remote Sensing 4, 1093-1101.

Li D, Chen Y, Shi Y et al., 2009: Impact of elevated $\mathrm{CO}_{2}$ and $\mathrm{O}_{3}$ concentrations on biogenic volatile organic compounds emissions from Ginkgo biloba. Bulletin of Environmental Contamination and Toxicology 82, 473-477.

Lindinger W, Jordan A, Hansel A, 1997: Proton-transfer-reaction mass spectroscopy (PTR-MS): On-line monitoring of volatile organic compounds at pptv levels. Chemical Society Reviews 27, 347-534.

Llusià J, Bermejo-Bermejo V, Calvete-Sogo H et al., 2014: Decreased rates of terpene emissions in Ornithopus compressus L. and Trifolium striatum L. by ozone exposure and nitrogen fertilization. Environmental Pollution 194, 69-77.

Loreto F, Fischbach RJ, Schnitzler JP et al., 2001: Monoterpene emission and monoterpene synthase activities in the Mediterranean evergreen oak Quercus ilex L. grown at elevated $\mathrm{CO}_{2}$ concentrations. Global Change in Biology 7, 709-717.

Loreto F, Sharkey TD, 1990: A gas-exchange study of photosynthesis and isoprene emission in Quercus rubra L. Planta 182, 523-531.

Loreto F, Velikova V, 2001: Isoprene produced by leaves protects the photosynthetic apparatus against ozone damage, quenches ozone products, and reduces lipid peroxidation of cellular membranes. Plant Physiology 127, 1781-1787.

Ludley KE, Jickells SM, Chamberlain PM et al., 2009: Distribution of monoterpenes between organic resources in upper soil horizons under monocultures of Picea abies, Picea sitchensis and Pinus sylvestris. Soil Biology \& Biochemistry 41, 1050-1059.

Mano J, 2012: Reactive carbonyl species: their production from lipid peroxides, action in environmental stress, and the detoxification mechanism. Plant Physiology and Biochemistry 59, 90-97.

Matsunaga SN, Chatani S, Nakatsuka S et al., 2012: Determination and potential importance of diterpene (kaur-16-ene) emitted from dominant coniferous trees in Japan. Chemosphere 87, 886-893.

McKinney KA, Lee BH, Vasta A et al., 2011: Emissions of isoprenoids and oxygenated biogenic volatile organic compounds from a New England mixed forest. Atmospheric Chemistry and Physics 11, 4807-4831.

Millet DB, Alwe HD, Chen X et al., 2018: Bidirectional ecosystem atmosphere fluxes of volatile organic compounds across the mass spectrum: How many matter? ACS Earth and
Space Chemistry 2, 764-777.

Misztal PK, Nemitz E, Langford B et al., 2011: Direct ecosystem fluxes of volatile organic compounds from oil palms in South-East Asia. Atmospheric Chemistry and Physics 11, 8995-9017.

Miyama T, Tobita H, Uchiyama K et al., 2018: Differences in monoterpene emission characteristics after ozone exposure between three clones representing major gene pools of Cryptomeria japonica. Journal of Agricultural Meteorology 74, 102-108.

Miyama T, Tobita H, Uchiyama K et al., 2019: Seasonal changes in interclone variation following ozone exposure on three major gene pools: An Analysis of Cryptomeria Japonica Clones. Atmosphere 10, 643.

Mochizuki T, Amagai T, Tani A, 2018: Effects of soil water content and elevated $\mathrm{CO}_{2}$ concentration on the monoterpene emission rate of Cryptomeria japonica. Science of the Total Environment 634, 900-908.

Mochizuki T, Kawamura K, Miyazaki Y et al., 2019: Distributions and sources of low-molecular-weight monocarboxylic acids in gas and particles from a deciduous broadleaf forest in northern Japan. Atmospheric Chemistry and Physics 19, 2421-2432.

Mochizuki T, Takanashi S, Wada R et al., 2020: Canopy fluxes of monoterpene, isoprene and isoprene oxidation products in a pine-oak forest. Journal of Agricultural Meteorology 76(1), 36-43.

Mochizuki T, Tani A, Takahashi Y et al., 2014: Long-term measurement of terpenoid flux above a Larix kaempferi forest using a relaxed eddy accumulation method. Atmospheric Environment 83, 53-61.

Mochizuki T, Watanabe M, Koike T et al., 2017: Monoterpene emissions from needles of hybrid larch F1 (Larix gmelinii var. japonica $\times$ Larix kaempferi) grown under elevated carbon dioxide and ozone. Atmospheric Environment 148, 197-202.

Monson RK, Trahan N, Rosenstiel TN et al., 2007: Isoprene emission from terrestrial ecosystems in response to global change: minding the gap between models and observations. Philosophical Transactions of the Royal Society A $\mathbf{3 6 5}$, 1677-1695.

Morishita T, Miyama T, Noguchi K et al., 2019: Spatiotemporal variations of below-ground monoterpene concentrations in an upland black spruce stand in interior Alaska. Polar Science 21, 158-164.

Muramoto S, Matsubara Y, Mwenda CM et al., 2015: Glutathionylation and reduction of methacrolein in tomato plants account for its absorption from the vapor phase. Plant Physiology 169, 1744-1754.

Nemecek-Marshall M, MacDonald RC, Franzen JJ et al., 1995: Methanol emission from leaves (Enzymatic detection of gas-phase methanol and relation of methanol fluxes to stomatal conductance and leaf development). Plant Physiology 108(4), 1359-1368.

Niinemets Ü, Fares S, Harley P et al., 2014: Bidirectional exchange of biogenic volatiles with vegetation: emission sources, reactions, breakdown and deposition. Plant, Cell \& Environment 37, 1790-1809.

Niinemets Ü, Tenhunen JD, Harley PC et al., 1999: A model of isoprene emission based on energetic requirements for isoprene synthesis and leaf photosynthetic properties for Liquidambar and Quercus. Plant, Cell \& Environment 22, 1319-1335.

Okumura M, Kosugi Y, Tani A, 2018: Biogenic volatile organic 
compound emissions from bamboo species in Japan. Journal of Agricultural Meteorology 74, 40-44.

Okumura M, Tani A, Tohno S et al., 2008: Light-dependent monoterpene emissions from an oak species native to Asia. Environmental Control in Biology 46, 257-265.

Omasa K, Tobe K, Hosomi M et al., 2000: Absorption of ozone and seven organic pollutants by Populus nigra and Camellia sasanqua. Environmental Science \& Technology 34, 2498-2500.

Pacifico F, Folberth GA, Jones CD et al., 2012: Sensitivity of biogenic isoprene emissions to past, present and future environmental conditions and implications for atmospheric chemistry. Journal of Geophysical Research 117, D22302.

Pacifico F, Harrison S, Jones C et al., 2009: Isoprene emissions and climate. Atmospheric Environment 43, 6121-6135.

Paulot F, Wunch D, Crounse JD et al., 2011: Importance of secondary sources in the atmospheric budgets of formic and acetic acids. Atmospheric Chemistry and Physics 11, 1989-2013.

Pegoraro E, Rey A, Greenberg J et al., 2004: Effect of drought on isoprene emission rates from leaves of Quercus virginiana Mill. Atmospheric Environment 38(36), 6149-6156.

Plaza J, Nunez L, Pujadas M et al., 2005: Field monoterpene emission of Mediterranean oak (Quercus ilex) in the central Iberian Peninsula measured by enclosure and micrometeorological techniques: Observation of drought stress effect. Journal of Geophysical Research 110, D03303.

Portillo-Estrada M, Zenone T, Arriga N et al., 2018: Contribution of volatile organic compound fluxes to the ecosystem carbon budget of a poplar short-rotation plantation. Global Change Biology Bioenergy 10, 405-414.

Possell M, Hewitt CN, 2011: Isoprene emissions from plants are mediated by atmospheric $\mathrm{CO}_{2}$ concentrations. Global Change Biology 17, 1595-1610.

Potosnak MJ, LeStourgeon L, Nunez O, 2014: Increasing leaf temperature reduces the suppression of isoprene emission by elevated $\mathrm{CO}_{2}$ concentration. Science of the Total Environment 481, 352-359.

Pressley S, Lamb B, Westberg $\mathrm{H}$ et al., 2005: Long-term isoprene flux measurements above a northern hardwood forest. Journal of Geophysical Research 110, D07301.

Räisänen T, Ryyppő A, Kellomäki S, 2008: Effects of elevated $\mathrm{CO}_{2}$ and temperature on monoterpene emission of Scots pine (Pinus sylvestris L.). Atmospheric Environment 42, 4160-4171.

Räisänen T, Ryyppö A, Kellomäki S, 2009: Monoterpene emission of a boreal Scots pine (Pinus sylvestris L.) forest. Agricultural and Forest Meteorology 149, 808-819.

Ren Y, Ge Y, Gu B et al., 2014: Role of management strategies and environmental factors in determining the emissions of biogenic volatile organic compounds from urban greenspaces. Environmental Science \& Technology 48, 6237-6246.

Ren Y, Qu Z, Du Y et al., 2017: Air quality and health effects of biogenic volatile organic compounds emissions from urban green spaces and the mitigation strategies. Environmental Pollution 230, 849-861.

Riemer D, Pos W, Milne P et al., 1998: Observations of nonmethane hydrocarbons and oxygenated volatile organic compounds at a rural site in the southeastern United States. Journal of Geophysical Research 103(D21), 28111-28128.

Rinne HJI, Delany AC, Greenberg JP et al., 2000: A true eddy accumulation system for trace gas fluxes using disjunct eddy sampling method. Journal of Geophysical Research 105, 24791-24798.
Rinne HJI, Guenther AB, Greenberg JP et al., 2002: Isoprene and monoterpene fluxes measured above Amazonian rainforest and their dependence on light and temperature. Atmospheric Environment 36, 2421-2426.

Rosenstiel TN, Potosnak MJ, Griffin KL et al., 2003: Increased $\mathrm{CO}_{2}$ uncouples growth from isoprene emission in an agriforest ecosystem. Nature 421, 256-259.

Sallas L, Kainulainen P, Utriainen J et al., 2001: The influence of elevated $\mathrm{O}_{3}$ and $\mathrm{CO}_{2}$ concentrations on secondary metabolites of Scots pine (Pinus sylvestris L.) seedlings. Global Change Biology 7, 303-311.

Schnitzler JP, Graus M, Kreuzwieser J et al., 2004: Contribution of different carbon sources to isoprene biosynthesis in poplar leaves. Plant Physiology 135, 152-160.

Scholefield PA, Doick KJ, Herbert BMJ et al., 2004: Impact of rising $\mathrm{CO}_{2}$ on emissions of volatile organic compounds: isoprene emission from Phragmites australis growing at elevated $\mathrm{CO}_{2}$ in a natural carbon dioxide spring. Plant, Cell \& Environment 27, 393-401.

Seco R, Karl T, Guenther A et al., 2015: Ecosystem-scale volatile organic compound fluxes during an extreme drought in a broadleaf temperate forest of the Missouri Ozarks (central USA). Global Change Biology 21, 3657-3674.

Seco R, Karl T, Turnipseed A et al., 2017: Springtime ecosystem-scale monoterpene fluxes from Mediterranean pine forests across a precipitation gradient. Agricultural and Forest Meteorology 237-238, 150-159.

Seco R, Peñuelas J, Filella I, 2007: Short-chain oxygenated VOCs: Emission and uptake by plants and atmospheric sources, sinks, and concentrations. Atmospheric Environment 41, 2477-2499.

Serca D, Guenther A, Klinger L et al., 2001: EXPRESSO flux measurements at upland and lowland Congo tropical forest site. Tellus 53B, 220-234.

Sharkey TD, Chen XY, Yeh S, 2001: Isoprene increases thermotolerance of fosmidomycin-fed leaves. Plant Physiology 125, 2001-2006.

Sharkey TD, Monson RK, 2014: The future of isoprene emission from leaves, canopies and landscapes. Plant, Cell \& Environment 37, 1727-1740.

Sharkey TD, Wiberley AE, Donohue AR, 2007: Isoprene emission from plants: why and how. Annals of Botany 100, 1-14.

Sharkey TD, Yeh SS, 2001: Isoprene emission from plants. Annual Review of Plant Physiology 52, 407-436.

Shrivastava M, Cappa CD, Fan J et al., 2017: Recent advances in understanding secondary organic aerosol: implications for global climate forcing. Reviews of Geophysics 55, 509-559.

Sindelarova K, Granier C, Bouarar I et al., 2014: Global data set of biogenic VOC emissions calculated by the MEGAN model over the last 30 years. Atmospheric Chemistry and Physics 14, 9317-9341.

Singsaas EL, Lerdau M, Winter K et al., 1997: Isoprene increases thermotolerance of isoprene-emitting species. Plant Physiology 115, 1413-1420.

Singh HB, Kanakidou M, Crutzen PJ et al., 1995: High concentrations and photochemical fate of oxygenated hydrocarbons in the global troposphere. Nature 378, 50-54.

Smolander A, Ketoka RA, Kotiaho T et al., 2006: Volatile monoterpenes in soil atmosphere under birch and conifers: Effects on soil N transformations. Soil Biology \& Biochemistry 38, 3436-3442.

Spirig C, Neftel A, Ammann C et al., 2005: Eddy covariance 
flux measurements of biogenic VOCs during ECHO 2003 using proton transfer reaction mass spectrometry. Atmospheric Chemistry and Physics 5, 465-481.

Staudt M, Bertin N, 1998: Light and temperature dependence of the emission of cyclic and acyclic monoterpenes from holm oak (Quercus ilex L.) leaves. Plant, Cell \& Environment 21, 385-395.

Staudt M, Seufert G, 1995: Light-dependent emission of monoterpenes by holm oak (Quercus ilex L.). Naturwissenschaften 82, 89-92.

Stavrakou T, Guenther A, Razavi A et al., 2011: First space-based derivation of the global atmospheric methanol emission fluxes. Atmospheric Chemistry and Physics 11, 4873-4898.

Sun Z, Hüve K, Vislap V et al., 2013: Elevated $\left[\mathrm{CO}_{2}\right]$ magnifies isoprene emissions under heat and improves thermal resistance in hybrid aspen. Journal of Experimental Botany 64, 5509-5523.

Sun Z, Niinemets Ü, Hüve K et al., 2012: Enhanced isoprene emission capacity and altered light responsiveness in aspen grown under elevated atmospheric $\mathrm{CO}_{2}$ concentration. Global Change Biology 18, 3423-3440.

Svendsen SH, Lindwall F, Michelsen A et al., 2016: Biogenic volatile organic compound emissions along a high arctic soil moisture gradient. Science of the Total Environment 573, 131-138.

Tani A, Hayward S, Hansel A et al., 2004: Effect of water vapour pressure on monoterpene measurements using proton transfer reaction - mass spectrometry (PTR-MS). International Journal of Mass Spectrometry 239, 161-169.

Tani A, Hayward S, Hewitt CN, 2003: Measurement of monoterpenes and related compounds by proton transfer reaction mass spectrometry (PTR-MS). International Journal of Mass Spectrometry 223, 561-578.

Tani A, Hewitt CN, 2009: Uptake of aldehydes and ketones at typical indoor concentrations by houseplants. Environmental Science \& Technology 43, 8338-8343.

Tani A, Kato S, Kajii Y et al., 2007: A proton transfer reaction mass spectrometry based system for determining plant uptake of volatile organic compounds. Atmospheric Environment 41, 1736-1746.

Tani A, Kawawata Y, 2008: Isoprene emission from the major native Quercus spp. in Japan. Atmospheric Environment 42, 4540-4550.

Tani A, Muramatsu K, Mochizuki T, 2020: Emission of methyl ethyl ketone and 2-butanol converted from methyl vinyl ketone in plant leaves. Atmosphere 11, 793.

Tani A, Nozoe S, Aoki M et al., 2002: Monoterpene fluxes measured above a Japanese red pine forest at Oshiba plateau, Japan. Atmospheric Environment 36, 3391-3402.

Tani A, Ohno T, Saito T et al., 2017: Effects of ozone on isoprene emission from two major Quercus species native to East Asia. Journal of Agricultural Meteorology 73(4), 195-202.

Tani A, Tobe S, Shimizu S, 2010: Uptake of methacrolein and methyl vinyl ketone by tree saplings and implications for forest atmosphere. Environmental Science \& Technology 44, 7096-7101.

Tani A, Tobe S, Shimizu S, 2013: Leaf uptake of methyl ethyl ketone and croton aldehyde by Castanopsis sieboldii and Viburnum odoratissimum saplings. Atmospheric Environment 70, 300-306.

Tani A, Tozaki D, Okumura M et al., 2011: Effect of drought stress on isoprene emission from two major Quercus species native to East Asia. Atmospheric Environment 45, 6261-6266.

Taylor TC, Mcmahon SM, Smith MN et al., 2018: Isoprene emission structures tropical tree biogeography and community assembly responses to climate. New Phytologist 220, 435-446.

Taylor TC, Smith MN, Slot M et al., 2019: The capacity to emit isoprene differentiates the photosynthetic temperature responses of tropical plant species. Plant, Cell \& Environment 42, 2448-2457.

Tingey DT, Evans R, Gumpertz M, 1981: Effects of environmental conditions on isoprene emission from live oak. Planta 152, 565-570.

Trapp S, Karlson U, 2001: Aspects of phytoremediation of organic pollutants. Journal of Soils and Sediments, 1, 37-43.

Tsuruta J, Okumura M, Makita N et al., 2018: A comparison of the biogenic volatile organic compound emissions from the fine roots of 15 tree species in Japan and Taiwan. Journal of Forest Research 23, 242-251.

Velikova V, Ghirardo A, Vanzo E et al., 2014: The genetic manipulation of isoprene emissions in poplar plants remodels the chloroplast proteome. Journal of Proteome Research 13, 2005-2018.

Velikova V, Tsonev T, Pinelli P et al., 2005: Localized ozone fumigation system for studying ozone effects on photosynthesis, respiration, electron transport rate and isoprene emission in field-grown Mediterranean oak species. Tree Physiology 25, 1523-1532.

Vickers CE, Gershenzon J, Lerdau MT et al., 2009a: A unified mechanism of action for volatile isoprenoids in plant abiotic stress. Nature Chemical Biology 5, 283-291.

Vickers CE, Possell MP, Cojocariu C et al., 2009b: Isoprene synthesis protects transgenic plants from oxidative stress. Plant, Cell \& Environment 32, 520-531.

Vuorinen T, Nerg AM, Vapaavuori E et al., 2005: Emission of volatile organic compounds from two silver birch (Betula pendula Roth) clones grown under ambient and elevated $\mathrm{CO}_{2}$ and different $\mathrm{O}_{3}$ concentrations. Atmospheric Environment 39, 1185-1197.

Wada R, Ueyama M, Tani A et al., 2020: Observation of vertical profiles of $\mathrm{NO}, \mathrm{O}_{3}$, and VOCs to estimate their sources and sinks by inverse modeling in a Japanese larch forest. Journal of Agricultural Meteorology 76, 1-10.

Westberg H, Lamb B, Kempf K et al., 2000: Isoprene emission inventory for the BOREAS southern study area. Tree Physiology 20, 735-743.

Wildermuth MC, Fall R, 1996: Light-dependent isoprene emission: characterization of a thylakoid-bound isoprene synthase in Salix discolor chloroplasts. Plant Physiology 112,171-182.

Wilkinson MJ, Owen SM, Possell M et al., 2006: Circadian control of isoprene emissions from oil palm (Elaeis guineensis). The Plant Journal 47, 960-968.

Yuan X, Calatayud V, Gao F et al., 2016: Interaction of drought and ozone exposure on isoprene emission from extensively cultivated poplar. Plant, Cell \& Environment 39(10), 2276-2287.

Yuan XY, Shang B, Xu YS et al., 2017: No significant interactions between nitrogen stimulation and ozone inhibition of isoprene emission in Cathay poplar. Science of the Total Environment 601, 222-229.

Zeinali N, Altarawneh M, Li D et al., 2016: New mechanistic insights: why do plants produce isoprene? ACS Omega 1, 220-225. 